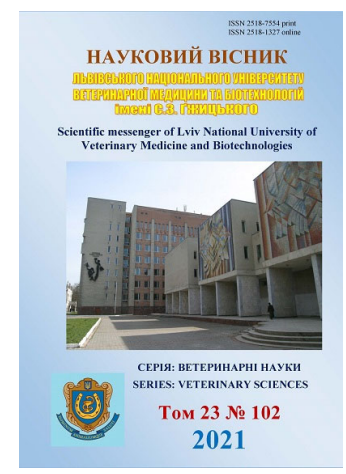

Науковий вісник Аьвівського національного університету ветеринарної медицини та біотехнологій імені С.3. Гжицького. Серія: Ветеринарні науки

\author{
Scientific Messenger of Lviv National University \\ of Veterinary Medicine and Biotechnologies. \\ Series: Veterinary sciences
}

doi: $10.32718 /$ nvlvet10206 https://nvlvet.com.ua/index.php/journal

UDC 619:616.981.842.17

\title{
Quantitative PCR analysis of intestinal microbiota in suckling piglets of different age groups with diarrhea
}

\author{
D. M. Masiuk, A. V. Kokariev, M. H. Supenko \\ Dnipro State Agrarian and Economic University, Dnipro, Ukraine
}

Article info

Received 04.03.2021

Received in revised form 06.04 .2021

Accepted 07.04.2021

Dnipro State Agrarian and Economic University, Serhiya Yefremova Str., 25, Dnipro, 49000, Ukraine.

Tel.: +38-050-636-62-37

E-mail:dimasiuk@gmail.com
Masiuk, D. M., Kokariev, A. V., \& Supenko, M. H. (2021). Quantitative PCR analysis of intestinal microbiota in suckling piglets of different age groups with diarrhea. Scientific Messenger of Lviv National University of Veterinary Medicine and Biotechnologies. Series: Veterinary sciences, 23(102), 37-42. doi: $10.32718 /$ nvlvet10206

The article presents the results of quantitative PCR detection of intestinal intestinal microbiota in suckling piglets of different age groups with diarrhea. To determine the etiology of diarrhea in piglets, 4 groups of animals were formed - two experimental and two control aged 3-5 and 17-21 days of life. Each group consisted of 6 piglets. The piglets in the experimental groups showed signs of diarrhea, and the pigs in the control groups were clinically healthy. Rectal smears were taken from piglets and immediately frozen at a temperature of $-18{ }^{\circ} \mathrm{C}--22{ }^{\circ} \mathrm{C}$ and stored in this form until laboratory examination. Isolation of genetic material from rectal smears was performed using a set of reagents for DNA/RNA extraction manufactured by Biosellal (France) on an automatic device "KingFisher Duo Prime" (USA). Performed mechanical lysis of biological material on the device for homogenization "FastPrep-24" (France). Specific regions of rotavirus RNA types $A$ and $C$ (PRVA, PRV C), the causative agent of swine diarrhea (PEDV) and Cl DNA fragments were determined in the purified nucleic acid solution. perfringens, E. coli, Cryptosporidium spp, Eimeria spr, Cystoisospora suis, as well as toxin-producing genes A and B Cl. difficile. Determinations of pathogenic E. coli was performed by toxin genes - STa, STb, LT, STX1, STX2 and EAE, as well as for by coding genes - F4, F5, F18 and F41. The obtained results of the study of the genetic material of microorganisms extracted from rectal smears from clinically healthy pigs and with manifestations of diarrhea characterize the state of the microbiome and the distribution of microorganisms in the intestines of suckling piglets. It was found that the species composition of intestinal microorganisms in clinically healthy suckling piglets is represented by two Cl bacteria. perfringens and E. coli with dominance of the latter, in the population of which there are trace amounts of enterotoxigenic forms. At the same time, it was found that diarrhea in piglets aged 3-5 days of age is induced by a pathogenic effect on the body of rotavirus type C, which is complicated by the effect of toxin synthesizing Cl. difficile, and in pigs 17-21 days of age-co-infection of rotavirus type $A$ and enterotoxigenic forms of $E$. coli.

Key words: diarrhea, suckling piglets, quantitative PCR, virulence genes, DNA, RNA.

\section{Кількісний ПЛР-аналіз кишкової мікробіоти у підсисних поросят різних вікових груп за діареї}

Д. М. Масюк, А. В. Кокарєв, М. Г. Супенко

Дніпровський державний аграрно-економічний університет, м. Дніпро, Украӥна

У статті наведено результати кількісного ПЛР-аналізу кишкової мікробіоти у підсисних поросят різних вікових груп за діареї. Для визначення етіології діареї у поросят було сформовано 4 групи тварин - дві дослідні та дві контрольні віком 3-5 та 17-21 доба життя. Кожна група налічувала по 6 поросят. Поросята дослідних груп мали ознаки діареї, а свині контрольних груп були клінічно здоровими. Від поросят відбирали ректальні мазки які одразу заморожувались при температурі $-18{ }^{\circ} \mathrm{C}--22{ }^{\circ} \mathrm{C}$ i у такому вигляді зберігались до лабораторного дослідження. Виділення генетичного матеріалу з ректальних мазків проводили за допомогою 
комплекту реактивів для екстракиії ДНК/РНК виробництва Biosellal (Франція) на автоматичному приладі “КingFisher Duо Prime” (США). Попередньо проводили механічний лізис біологічного матеріалу на приладі для гомогенізації “FаstPrер-24” (Франція). У очищеному розчині нуклеїнових кислот визначали специфічні ділянки PHК ротавірусу типів $A$ i C (PRV A, PRV C), збуднику епідемічної діареї свиней (PEDV) та фрагменти ДНК Cl. perfringens, E. coli, Cryptosporidium spp, Eimeria spp, Cystoisospora suis, a також токсин продукуючі гени A i B Cl. difficile. Визначення патогенних E. coli проводили за шістьма токсин кодуючими генами STa, STb, LT, STX1, STX2 і EAE, а також за адгезин кодуючими генами - F4, F5, F18 і F41. Отримані результати дослідження генетичного матеріалу мікроорганізмів екстрагованого з ректальних мазках від свиней клінічно здорових та з проявами діареї характеризують стан мікробіому та розподіл мікроорганізмів у кишечнику підсисних поросят. Встановлено, щзо видовий склад мікроорганізмів кишечнику клінічно здорових підсисних поросят представлений двома бактеріями Cl. pеrfringens та E. соli з домінуванням останньої, у популяиї якої присутні слідові кількості ентеротоксигенних форм кишкової палички. Одночасно з циим з 'ясовано, що діареї у поросят віком 3-5 діб життя індуковані патогенною дією на організм ротавірусу типу С, щзо ускладнюється впливом В токсин синтезуючої Cl. difficile, а у свиней 17-21 добового віку - коінфекцією ротавірусу типу А та ентеротоксигенних форм E. coli.

\section{Ключові слова: діареї, підсисні поросята, кількісний ПЛР, гени вірулентності, ДНК, РНК}

\section{Вступ}

Кишкові інфекції є однією з найпоширеніших патологій свиней у всьому світі, що сприяє формуванню значних економічних збитків свинарській галузі (Schulz \& Tonsor, 2015). Найбільш чутливими до патогенного впливу мікроорганізмів є поросята підсисного періоду та після відлучення, що пов'язано із становленням у них імунної системи в продовж неонатального періоду та катаболізмом колостральних антитіл, а також імуносупресивною дією стресових факторів на організм свиней (Yefimov et al., 2016; Masiuk et al., 2019; Martyshuk et al., 2019; 2020).

3 огляду на те, що кишечник колонізують як мікроорганізми-коменсали так і патогенні форми бактерій, останні, зазвичай, ускладнюють перебіг патологічного процесу та лабораторну діагностику. Слід відзначити, що індукуючи запалення кишечнику мікроорганізми порушують процеси травлення та всмоктування, що обумовлює розвиток діарейного синдрому, на тлі чого тварини швидко худнуть і гинуть (Masiuk et al., 2018). Саме тому важливим завданням у лабораторній діагностиці кишкових інфекцій $є$ визначення етіологічного чиннику ентероколітів у поросят і виявлення домінуючого у патологічному процесі патогену.

На сьогодні одним 3 найбільш розповсюджених методів лабораторної діагностики є полімеразна ланцюгова реакція (ПЛР), принцип якої базується на реплікації генетичного матеріалу мікроорганізму in vitro. Здатність цього методу враховувати результати дослідження у режимі реального часу дозволяє визначити кількість геном-еквівалентів збуднику, що вказує на домінування того чи іншого мікроорганізму у патологічному процесі (Salminen et al., 2015).

3 огляду на це особливої актуальності набувають дослідження $з$ диференціальної діагностики шлунково-кишкових інфекцій у підсисних поросят методом полімеразної ланцюгової реакції.

Саме тому метою нашої роботи було провести кількісний ПЛР-аналіз кишкової мікробіоти у підсисних поросят різних вікових груп за діареї.

\section{Матеріал і методи досліджень}

Виробничі дослідження проведені на базі сільськогосподарського підприємства 3 вирощування сви- ней загальною кількістю поголів'я 62 тис. тварин, а лабораторні дослідження виконані в умовах ПЛРлабораторії відділу імунохімічного та молекулярногенетичного аналізу науково-дослідного центру біобезпеки та екологічного контролю ресурсів агропромислового комплексу Дніпровського державного аграрно-економічного університету (НДЦ).

Для визначення етіології діареї у підсисних поросят було сформовано 4 групи тварин - дослідну і контрольну віком 3-5 і 17-21 доби життя. Кожна група налічувала по 6 поросят з різних гнізд. Поросята дослідних груп мали ознаки діареї, а свині контрольних груп були клінічно здоровими.

Від поросят відбирали ректальні мазки у свеби без транспортного середовища. Мазки були одразу замороженими при температурі $-18{ }^{\circ} \mathrm{C}--22{ }^{\circ} \mathrm{C}$ і у замороженому вигляді транспортувались до НДЦ.

Виділення генетичного матеріалу з ректальних мазків проводили за допомогою комплекту реактивів для екстракції ДНК/РНК виробництва Biosellal (Франція) на автоматичному приладі “KingFisher Duo Prime" (США), попередньо провівши механічний лізис біологічного матеріалу на приладі для гомогенізації "FastPrep-24" (Франція).

У очищеному розчині нуклеїнових кислот визначали специфічні ділянки РНК ротавірусу типів А і C (PRV A, PRV C), збуднику епідемічної діареї свиней $(P E D V)$ та унікальні фрагменти ДНК $C l$. perfringens, E. coli, Cryptosporidium spp, Eimeria spp, Cystoisospora suis, а також токсин продукуючі гени А i B Cl. difficile.

Визначення патогенних форм E. coli проводили за шістьма токсин кодуючими генами - термостабільним токсином А (STa), термостабільним токсином В (STb), термолабільним токсином (LT), шиготоксинами - STX1 і STX2 та інтиміном (EAE), а також за адгезин кодуючими генами - F4, F5, F18 i F41.

Дослідження вище перелічених показників проводили методом ПЛР з детекцією результатів у режимі реального часу за допомогою відповідних тестнаборів фірми ЕXOPOL (Іспанія).

Ампліфікацію, детекцію та інтерпретацію результатів проводили на приладі "BioRad CFX96" (США) за рекомендаціями, що наведені в інструкції до використання відповідних тест-систем.

Розрахунок кількості генетичного матеріалу ідентифікованих мікроорганізмів у ампліфікованій алік- 
воті проводили автоматично за допомогою програмного забезпечення до приладу "BioRad CFX96" згідно настанови до його використання. Калібрувальні графіки будували за допомогою стандартизованих позитивних контрольних зразків, які входять до складу діагностичних тест-систем для ПЛР дослідження.

Біометричну обробку експериментальних даних проводили статистично 3 розрахунком $\mathrm{t}$-критерію достовірності Стьюдента за допомогою програмного забезпечення Microsoft Excel з використанням вбудованих статистичних функцій. Результати середніх значень вважали статистично вірогідними при $*_{-} \mathrm{P}<0,05 ; * *-\mathrm{P}<0,01 ; * * *-\mathrm{P}<0,001$.

\section{Результати та їх обговорення}

Отримані результати дослідження генетичного матеріалу мікроорганізмів екстрагованого 3 ректальних мазках від свиней клінічно здорових та 3 проявами діареї характеризують стан мікробіому та розподіл мікроорганізмів у кишечнику підсисних поросят.

Встановлено, що у всіх клінічно здорових поросят 3-5 добового віку кишечник колонізує E. coli та у трьох з шести $-C l$. perfringens, кількість останньої $є$ у 100 разів меншою порівняно до значень кишкової палички, про що свідчать результати кількісного ПЛР-дослідження унікальних фрагментів ДНК цих мікроорганізмів (табл. 1).

\section{Таблиця 1}

Результати кількісного ПЛР дослідження генетичного матеріалу мікроорганізмів кишечнику поросят 3-5 діб життя $(\mathrm{M} \pm \mathrm{m}, \mathrm{n}=6)$

\begin{tabular}{|c|c|c|c|c|}
\hline \multirow{3}{*}{ Мікроорганізми } & \multicolumn{4}{|c|}{ Групи тварин } \\
\hline & \multicolumn{2}{|l|}{ Дослідна } & \multicolumn{2}{|c|}{ Контрольна } \\
\hline & Позитивні тварини, \% & г.-е., копій & Позитивні тварини, \% & г.-е., копій \\
\hline$P R V A$ & 0 & - & 0 & - \\
\hline$P R V C$ & 100 & $\begin{array}{c}1,75 \times 10^{9} \pm \\
9,02 \times 10^{8}\end{array}$ & 0 & - \\
\hline$P E D V$ & 0 & - & 0 & - \\
\hline Cl. perfringens & 100 & $\begin{array}{c}2,04 \times 10^{7} \pm \\
9,16 \times 10^{6}\end{array}$ & 50 & $\begin{array}{l}6,63 \times 10^{5} \pm \\
2,47 \times 10^{5 *}\end{array}$ \\
\hline Cl. difficile & 33 & $\begin{array}{c}4,94 \times 10^{5} \pm \\
4,04 \times 10^{4}\end{array}$ & 0 & - \\
\hline Cryptosporidium spp & 0 & - & 0 & - \\
\hline Eimeria spp & 0 & - & 0 & - \\
\hline Cystoisospora suis & 0 & - & 0 & - \\
\hline E. coli & 100 & $\begin{array}{c}5,78 \times 10^{7} \pm \\
2,53 \times 10^{7}\end{array}$ & 100 & $\begin{array}{c}4,43 \times 10^{7} \pm \\
2,27 \times 10^{7}\end{array}$ \\
\hline
\end{tabular}

Примітка: тут і надалі: г.-е. - геном-еквіваленти; $*-\mathrm{P} \leq 0,05 ; * *-\mathrm{P} \leq 0,01 ; * * *-\mathrm{P} \leq 0,001$ порівняно до значень тварин контрольної групи

Дослідження ректальних мазків від поросят 3-5 діб життя з ознаками діареї вказують на присутність в усіх пробах генетичного матеріалу ротавірусу типу C, бактерій $\mathrm{Cl}$. perfringens і $\mathrm{E}$. coli, а у двох тварин 3 шести ще В токсин синтезуючу $\mathrm{Cl}$. difficile. Порівнюючи кількість геном-еквівалентів збуднику встановлено, що домінуючим мікроорганізмом у поросят 3 діареєю є ротавірус типу C, тоді як у клінічно здорових тварин цієї вікової групи він взагалі відсутній. Одночасно 3 цим кількість генетичного матеріалу E. coli та $C l$. perfringens між собою суттєво не відрізняються, проте кількість $\mathrm{Cl}$. perfringens є достовірно більшою в 100 разів ( $\leq 0,01)$ порівняно до значень отриманих від клінічно здорових тварин. Найменшу кількість генетичного матеріалу у поросят 3 діареєю виявлено за показником В токсин кодуючої Cl. difficile.

Слід зауважити, що E. coli та $C l$. perfringens є нормальними представниками мікробіоти кишечнику поросят (Fernandez-Miyakawa \& Redondo, 2018), тоді як ротавірус типу С та токсин В синтезуюча Cl. difficile є патогенними мікроорганізмами, які здатні самостійно індукувати ентерит у поросят (Wakuda et al., 2011; Chumbler et al., 2012).

Отже, у кишечнику склад мікроорганізмів клінічно здорових поросят 3-5-добового віку виявлено дві бактерії-E. coli та $C l$. perfringens, а у поросят з ознаками діареї чотири мікроорганізми - ротавірус типу $\mathrm{C}, \mathrm{Cl}$. perfringens, $\mathrm{E}$. coli та $\mathrm{Cl}$. difficile. Домінуючим мікроорганізмом у кишечнику клінічно здорових поросят віком 3-5 діб життя є E. coli, а у поросят цього віку з ознаками діареї - ротавірус типу C.

Результати дослідження генетичних факторів вірулентності E. coli у поросят 3-5-добового віку як дослідної так і контрольної груп вказують на присутність у бактерій генів термостабільного токсину В та термолабільного токсину, а також фактору адгезії F4 (табл. 2), що характеризує їх як ентеротиксигенні форми E. coli (Cornick et al., 2000). 


\section{Таблиця 2}

Результати ПЛР-дослідження генетичних факторів вірулентності E. coli у кишечнику підсисних поросят 3-5добового віку $(\mathrm{M} \pm \mathrm{m}, \mathrm{n}=6)$

\begin{tabular}{|c|c|c|c|c|}
\hline \multirow{3}{*}{$\begin{array}{c}\text { Фактори вірулентності } \\
\text { E. coli }\end{array}$} & \multicolumn{4}{|c|}{ Групи тварин } \\
\hline & \multicolumn{2}{|c|}{$\begin{array}{r}\text { Дослідна } \\
\end{array}$} & \multicolumn{2}{|c|}{ Контрольна } \\
\hline & Позитивні тварини, \% & г.-е., копій & Позитивні тварини, \% & г.-е., копій \\
\hline E. coli & 100 & $\begin{array}{c}5,78 \times 10^{7} \pm \\
2,53 \times 10^{7}\end{array}$ & 100 & $\begin{array}{c}4,43 \times 10^{7} \pm \\
2,27 \times 10^{7}\end{array}$ \\
\hline STa & 0 & - & 0 & - \\
\hline $\mathrm{STb}$ & 100 & $\begin{array}{l}3,77 \times 10^{4} \pm \\
2,05 \times 10^{4} \mathrm{xx}\end{array}$ & 33 & $\begin{array}{l}2,24 \times 10^{4} \pm \\
1,14 \times 10^{4 \mathrm{xx}}\end{array}$ \\
\hline LT & 100 & $\begin{array}{l}1,57 \times 10^{4} \pm \\
1,06 \times 10^{4} \mathrm{xx}\end{array}$ & 33 & $\begin{array}{l}8,01 \times 10^{4} \pm \\
4,28 \times 10^{4} \mathrm{xx}\end{array}$ \\
\hline STX1 & 0 & - & 0 & - \\
\hline STX2 & 0 & - & 0 & - \\
\hline EAE & 0 & - & 0 & - \\
\hline F4 & 100 & $\begin{array}{c}5,98 \times 10^{4} \pm \\
3,30 \times 10^{4} \mathrm{xx}\end{array}$ & 33 & $\begin{array}{l}1,98 \times 10^{4} \pm \\
1,08 \times 10^{4} \mathrm{xx}\end{array}$ \\
\hline F5 & 0 & - & 0 & - \\
\hline F18 & 0 & - & 0 & - \\
\hline F41 & 0 & - & 0 & - \\
\hline
\end{tabular}

Порівнюючи співвідношення токсигенних та адгезин продукуючих форм E. coli встановлено, що у поросят 3-5-добового віку як дослідної так і контрольної груп кількість ентеротоксигенних форм бактерій у 1000 разів $(\mathrm{P} \leq 0,01)$ є меншою порівняно до загальної кількості бактерій E. coli. За даними Daniel Dubreuil (2008) кількість ентеротоксигенних форм E. coli яка не перевищує співвідношення - 1 патогенної бактерії на 1000 умовно-патогенних іiі форм $є$ недостатньою для індукції ентериту у свиней.
Отже, у кишечнику $100 \%$ підсисних поросят 3 ознаками діареї та у 33 \% клінічно здорових тварин присутні ентеротиксигенні форми E. coli, кількість яких не перевищує 1/1000 умовно-патогенних форм бактерій.

Результати дослідження генетичного матеріалу мікробіоти кишечнику клінічно здорових поросят 17-21 доби життя вказують на присутність у всіх тварин ДНК E. coli та у чотирьох 3 шести свиней Cl.perfringens, при цьому кількість останньої є у 10 разів меншою за значення E. coli (табл. 3).

\section{Таблиця 3}

Результати кількісного ПЛР дослідження генетичного матеріалу мікроорганізмів кишечнику поросят 17-21 доби життя $(\mathrm{M} \pm \mathrm{m}, \mathrm{n}=6)$

\begin{tabular}{|c|c|c|c|c|}
\hline \multirow{3}{*}{ Мікроорганізми } & \multicolumn{4}{|c|}{ Групи тварин } \\
\hline & \multicolumn{2}{|l|}{ Дослідна } & \multicolumn{2}{|c|}{ Контрольна } \\
\hline & Позитивні тварини, \% & г.-е., копій & Позитивні тварини, \% & г.-е., копій \\
\hline$P R V A$ & 100 & $\begin{array}{c}1,26 \times 10^{10_{ \pm}} \\
9,24 \times 10^{9}\end{array}$ & ( & - \\
\hline$P R V C$ & 0 & - & 0 & - \\
\hline$P E D V$ & 0 & - & 0 & - \\
\hline Cl. perfringens & 83 & $\begin{array}{c}4,75 \times 10^{6} \pm \\
2,59 \times 10^{6}\end{array}$ & 67 & $\begin{array}{c}1,04 \times 10^{7} \pm \\
8,86 \times 10^{6}\end{array}$ \\
\hline Cl. difficile & 0 & - & 0 & - \\
\hline Cryptosporidium spp & 0 & - & 0 & - \\
\hline Eimeria $s p$ & 0 & - & 0 & - \\
\hline Cystoisospora suis & 0 & - & 0 & - \\
\hline E. coli & 100 & $\begin{array}{c}3,53 \times 10^{10_{ \pm}} \\
1,40 \times 10^{10}\end{array}$ & 100 & $\begin{array}{c}5,59 \times 10^{8} \pm \\
2,45 \times 10^{8 * *}\end{array}$ \\
\hline
\end{tabular}

У всіх поросят з ознаками діареї, окрім генетичного матеріалу E. coli та Cl. perfringens, виявлено РНК ротавірусу типу А, який здатний самостійно індукувати ентерити у підсисних поросят та свиней після відлучення (Vlasova et al., 2017). При цьому серед ідентифікованих мікроорганізмів у ректальних мазках переважає ротавірус типу А та E. coli. Кількість останньої переважає значення клінічно здорових тва- рин цього віку у 100 разів (Р $\leq 0,01)$, що вказує на колонізацію кишечнику поросят 3 клінічними ознаками діареї кишковою паличкою.

Отже, домінуючим мікроорганізмом у кишечнику клінічно здорових поросят 17-21-добового віку $\epsilon$ E. coli, тоді як у мікробіомі поросят з ознаками діареї переважають одразу два мікроба - ротавірус типу А та E. coli. Це узгоджується 3 результатами Juliet 
Chepngeno (2019), яка із співавторами з'ясувала, що у поросят перших діб життя частіше за все ентерити індуковані атиповими формами ротавірусів, а у більш старших тварин класичним ротавірусом типу А. Таку закономірність автори пов'язують 3 наявністю у поросят колострального імунітету до класичного ротавірусу, який формується на тлі імунопрофілактичних щеплень свиноматок, та відсутністю материнського захисту проти атипових форм ротавірусу.
Результати дослідження генів факторів вірулентності $E$. coli вказують на низький рівень превалентності у клінічно здорових поросят 17-21-добового віку токсин та адгезин синтезуючих форм E. coli порівняно до загальної кількості бактерій кишкової палички, що складає у середньому від $1 / 1000$ до $1 / 10000$ (P $\leq 0,01$ $0,001)$ умовно-патогенних форм E. coli (табл. 4).

\section{Таблиця 4}

Результати ПЛР-дослідження генетичних факторів вірулентності E. coli у кишечнику підсисних поросят 17-21добового віку $(\mathrm{M} \pm \mathrm{m}, \mathrm{n}=6)$

\begin{tabular}{|c|c|c|c|c|}
\hline \multirow{3}{*}{$\begin{array}{c}\text { Фактори вірулентності } \\
\text { E. coli }\end{array}$} & \multicolumn{4}{|c|}{ Групи тварин } \\
\hline & \multicolumn{2}{|c|}{ Дослідна } & \multicolumn{2}{|c|}{ Контрольна } \\
\hline & Позитивні тварини, \% & г.-е., копій & Позитивні тварини, \% & г.-е., копій \\
\hline E. coli & ( & $\begin{array}{c}3,53 \times 10^{10} \pm \\
1,40 \times 10^{10}\end{array}$ & (t) & $\begin{array}{c}5,59 \times 10^{8} \pm \\
2,45 \times 10^{8}\end{array}$ \\
\hline STa & 0 & - & 0 & - \\
\hline $\mathrm{STb}$ & 100 & $\begin{array}{c}3,03 \times 10^{10_{ \pm}} \\
9,73 \times 10^{9}\end{array}$ & 33 & $\begin{array}{c}6,18 \times 10^{5} \pm \\
3,26 \times 10^{4 \times x x}\end{array}$ \\
\hline $\mathrm{LT}$ & 100 & $\begin{array}{l}1,95 \times 10^{10_{ \pm}} \\
8,41 \times 10^{9}\end{array}$ & 33 & $\begin{array}{l}4,25 \times 10^{5} \pm \\
3,03 \times 10^{5 \times x x}\end{array}$ \\
\hline STX1 & 0 & - & 0 & - \\
\hline STX2 & 0 & - & 0 & - \\
\hline EAE & 0 & - & 0 & - \\
\hline $\mathrm{F} 4$ & 100 & $\begin{array}{c}2,66 \times 10^{10_{ \pm}} \\
1,77 \times 10^{10}\end{array}$ & 33 & $\begin{array}{c}7,38 \times 10^{4} \pm \\
3,67 \times 10^{4} \mathrm{xxx}\end{array}$ \\
\hline F5 & 0 & - & 0 & - \\
\hline F18 & 0 & - & 0 & - \\
\hline F41 & 0 & - & 0 & - \\
\hline
\end{tabular}

Дослідження наявності токсин та адгезин кодуючих генів у $E$. coli ізольованої від свиней 17-21добового віку з ознаками діареї встановлено, що вся популяція кишкової палички, яка знаходиться у кишечнику свиней володіє генетичними факторами вірулентності та здатна синтезувати ентеротоксини і фактор адгезії $\mathrm{F} 4$, завдяки яким E. coli колонізує слизову оболонку тонкої кишки та індукує іії запалення.

Отже, серед пулу бактерій E. coli ізольованої з кишечнику клінічно здорових поросят 17-21-добового віку лише 1/1000 частка володіє генетичними факторами вірулентності, що $є$ недостатнім для розвитку ентериту, проте $\epsilon$ потенційним етіологічним фактором виникнення діареї свиней у майбутньому, на тлі інтенсивної колонізації слизової тонкого відділу кишечнику патогенними формами кишкової палички. У тварин $з$ ознаками діареї всі ідентифіковані форми E. coli є ентеротоксигенними, а відповідно здатні як самостійно викликати ентерит у свиней так і ускладнювати вже індукований раніше інфекційний процес.

\section{Висновки}

1. Видовий склад мікроорганізмів кишечнику клінічно здорових підсисних поросят представлений двома бактеріями $C l$. perfringens та E. coli $з$ домінуванням останньої, у популяції якої присутні слідові кількості ентеротоксигенних форм кишкової палички.

2. Діареї у поросят віком 3-5 діб життя індуковані патогенною дією на організм ротавірусу типу С, що ускладнюється впливом В токсин синтезуючої Cl. difficile, а у свиней 17-21 добового віку - коінфекцією ротавірусу типу А та ентеротоксигенними формами E. coli.

Відомості про конфлікт інтересів. Автори стверджують про відсутність конфлікту інтересів щодо їх вкладу та результатів досліджень.

\section{References}

Chepngeno, J., Diaz, A., Paim, F. C., Saif, L. J., Vlasova, A. N. (2019). Rotavirus C: prevalence in suckling piglets and development of virus-like particles to assess the infuence of maternal immunity on the disease development. Vet Re., 50, 84-96. doi: 10.1186/s13567019-0705-4.

Chumbler, N. M., Farrow, M. A., Lapierre, L. A., Lapierre, A., Franklin, J. L., Haslam, D. et al. (2012). Clostridium difficile Toxin B causes epithelial cell necrosis through an autoprocessing-independent mechanism. PLoS Pathog, 8(12), e1003072. doi: 10.1371/journal.ppat.1003072.

Cornick, N. A., Matise, I., Samuel, J. E., Bosworth, B. T., \& Moon, H. W. (2000). Shiga toxin-producing Escherichia coli infection: temporal and quantitative relationships among colonization, toxin production, and systemic disease. Journal of Infectious Diseases, 181, 242-251. doi: 10.1086/315172. 
Dubreuil, D. (2008). Escherichia coli STb toxin and colibacillosis: knowingis halfthe battle. FEMS Microbiology Letters, 278, 137-145. doi: 10.1111/j.15746968.2007.00967.x.

Fernandez-Miyakawa, M. E., \& Redondo, L. M. (2018). Role of Clostridium perfringens alpha, beta, epsilon, and iota toxins in enterotoxemia of monogastrics and ruminants. Microbial Toxins. Toxinology. Springer. Dordrecht, 93-118. doi: 10.1007/978-94-007-6449116.

Martyshuk T. V., Gutyj B. V., \& Vishchur O. I. (2019). Morphological and biochemical indices of piglets' blood by the action of feed additive "Butaselmevitplus". The Animal biology, 21(4), 65-70. doi: 10.15407/animbiol21.04.065.

Martyshuk, T. V., Gutyj, B. V., Vishchur, O. I., \& Todoriuk, V. B. (2019). Biochemical indices of piglets blood under the action of feed additive "Butaselmevitplus". Ukrainian Journal of Veterinary and Agricultural Sciences, 2(2), 27-30. doi: 10.32718/ujvas2-2.06.

Martyshuk, T. V., Gutyj, B. V., Zhelavskyi, M. M., Midyk. S. V., Fedorchenko, A. M., Todoriuk, V. B., Nahirniak, T. B., Kisera, Ya. V., Sus, H. V., Chemerys, V. A., Levkivska, N. D., \& Iglitskej, I. I. (2020). Effect of Butaselmevit-Plus on the immune system of piglets during and after weaning. Ukrainian Journal of Ecology, 10(2), 347-352. doi: 10.15421/2020_106.

Masiuk, D. M., Kokariev, A. V., Vasilenko, T. O., \& Krutii, K. O. (2019). The formation of colostrial immunity and its duration in calves during the first month of life. Ukrainian Journal of Veterinary and Agricultural Sciences, 2(1), 3-6. doi: 10.32718/ujvas2-1.01.

Masiuk, D. N., Nedzvetsky, V. S., Sosnitskiy, A. I., Kokarev, A. V., \& Koliada, S. G. (2018). The characteristics, emergent properties and manner of spread in Ukraine of the Porcine Epidemic Diarrhea Virus. Regulatory Mechanisms in Biosystems,9(3), 401-408. doi: 10.15421/021860.

Salminen, A., Kopra, E.K.A., Hyvärinen, K., Paju, S., Mäntylä, P., Buhlin, K. et al. (2015). Quantitative PCR analysis of salivary pathogen burden in periodontitis. Front. Cell. Infect. Microbiol., 69(5), 1-10. doi: 10.3389/fcimb.2015.00069.

Schulz, L. L., \& Tonsor, G. T. (2015). Assessment of the economic impacts of porcine epidemic diarrhea virus in the United States. Journal of Animal Science, 93(11), 5111-5118. doi: 10.2527/jas.2015-9136.

Vlasova, A. N., Amimo, J. O., \& Saif, L. J. (2017). Porcine rotaviruses: epidemiology, immune responses and control strategies. Viruses, 9, 48-75. doi: 10.3390/v9030048.

Wakuda, M. T., Sasaki, J., Komoto, S., Ishii, J., Sanekata, T., \& Taniguchi, K. (2011). Porcine rotavirus closely related to novel group of human rotaviruses. Emerging Infectious Diseases, 17, 1491-1493. doi: 10.3201/eid1708.101466.

Yefimov, V., Kostiushkevych, K., \& Rakytianskyi, V. (2016). Effect of feeding treated peat as a supplement on the parameters of cellular immunity, antioxidant status and performance of piglets in early postweaning period. Human \& Veterinary Medicine, 8(3), 133-136. 